\begin{tabular}{|} 
Ambiente \& Água - An Interdisciplinary Journal of Applied Science \\
ISSN 1980-993X - doi:10.4136/1980-993X \\
www.ambi-agua.net \\
E-mail: ambi.agua@gmail.com
\end{tabular}

\title{
Filling gaps in the knowledge of grouper, especially Comb grouper (Mycteroperca acutirostris) (2013-2020) (Copacabana fishery, Rio de Janeiro, Brazil) ${ }^{1}$
}

\author{
ARTICLES doi:10.4136/ambi-agua.2774
}

Received: 22 Jul. 2021; Accepted: 05 Dec. 2021

\author{
Alpina Begossi ${ }^{1,2,3 *(D)}$; Svetlana Salivonchyk ${ }^{4}{ }^{D}$; Branko Glamuzina ${ }^{5}{ }^{(D}$; \\ Alessandro Alves-Pereira ${ }^{6}{ }^{(D)}$; Carlos Eduardo De Araujo Batista ${ }^{7}$; \\ Regina Helena Geribello Priolli1,2 ${ }^{1 D}$
}

\footnotetext{
${ }^{1}$ Núcleo de Estudos e Pesquisas em Alimentação (NEPA). Universidade Estadual de Campinas (UNICAMP), Rua Albert Einstein, n 291, CEP: 13083-852, Campinas, SP, Brazil. E-mail: albegossi@gmail.com ${ }^{2}$ Fisheries and Food Institute (FIFO), Rua Sousa Lima, n 16/1101, CEP: 22081-010, Rio de Janeiro, RJ, Brazil. E-mail: fifo@fisheriesandfood.com,rhpriolli@gmail.com

${ }^{3}$ Programa de Pós-Graduação em Ciências Ambientais/Sustentabilidade. Universidade Santa Cecília (Unisanta), Rua Oswaldo Cruz, n 277, CEP: 11045-907, Boqueirão, SP, Brazil.

${ }^{4}$ Institute for Nature Management. Department of Chemistry and Earth Sciences. Laboratory on Transboundary Pollution. National Academy of Sciences of Belarus, Skoriny str. 10, 220114, Minsk, Belarus. E-mail: salivonchyk@yahoo.co.uk

${ }^{5}$ Department of Applied Ecology. University of Dubrovnik, Branitelja Dubrovnika, 29, 20000, Dubrovnik, Croatia. E-mail: branko.glamuzina@unidu.hr

${ }^{6}$ Instituto de Biologia. Departamento de Biologia Vegetal. Universidade Estadual de Campinas (UNICAMP), Avenida Cândido Rondon, n 400, CEP: 13083-875, Campinas, SP, Brazil. E-mail: ale.alves.pereira@gmail.com

${ }^{7}$ Departamento de Genética. Escola Superior de Agricultura "Luiz de Queiroz". Universidade de São Paulo (USP), Avenida Pádua Dias, n¹1, CEP: 13418-900, Piracicaba, SP, Brazil. E-mail: batistace@ gmail.com *Corresponding author. E-mail: albegossi@gmail.com
}

\section{ABSTRACT}

There are gaps in our knowledge of important fish consumed by people in tropical countries. Small-scale fisheries are difficult to regulate, especially in countries with no species monitoring. At Copacabana (Rio de Janeiro), we observed 490 individuals of badejo (Comb grouper) (Mycteropeca acutirostris in 2013-2014 and in 2018-2020. The average catch was $1.36 \mathrm{~kg}(\mathrm{n}=466$ individuals). A pattern of decreasing catches was observed for Comb grouper.

${ }^{1}$ A version of this study is in: bioRxiv preprint doi: https://doi.org/10.1101/2021.04.12.439484; this version posted April 13, 2021. The copyright holder for this preprint (which was not certified by peer review) is the author/funder, who has granted bioRxiv a license to display the preprint in perpetuity. It is made available under aCC-BY-NC-ND 4.0 International license. 
Therefore, provided that the fishing gear and the number of fish have remained the same, the apparent decrease in Comb grouper needs to be further investigated. The results provide information about the major spawning season, around spring (September-December) with additional spawning during April. Genetic analyses in samples from 96 grouper obtained along the coast of Brazil were conducted. The Single Nucleotide Polymorphism (SNP) loci obtained for grouper species enabled us to determine the relative genetic proximity of $M$. acutirostris and Mycteroperca bonaci, information that can be useful for aquaculture and conservation. The objectives of this study were: a) to obtain data about the fishing activity (catch landings) of Comb groupers at Copacabana, Posto 6; b) to verify the reproductive period of Comb grouper, throughout the year, through the catches from the fishery; c) to develop a large numbers of SNP markers, which can be useful to studies about grouper populations (Mycteroperca and Epinephelus); and, d) to obtain data on the price of the Comb grouper. This study contributes data on the fishery and on the biology and ecology of groupers, and further contributes to conservation efforts.

Keywords: comb grouper, fisheries, genetics, Mycteroperca.

\section{Preenchendo lacunas no conhecimento das garoupas, especialmente de Mycteroperca acutirostris (2013-2020) (Copacabana fishery, Rio de Janeiro, Brazil)}

\section{RESUMO}

Existem lacunas em nosso conhecimento sobre a biologia de peixes importantes no consumo em países tropicais. A pesca em pequena escala é difícil de estudar e regulamentar, especialmente em países sem monitoramento sistemático de espécies. Em Copacabana (Rio de Janeiro) observamos 490 indivíduos de badejo (Mycteropeca acutirostris), nas pescarias, em 2013-2014 e 2018-2020. O kg médio dos badejos pescados foi de 1,36kg (n=466 indivíduos). Observou-se um padrão decrescente de capturas para o badejo. Portanto, considerando que a tecnologia pesqueira e o número de pescadores permaneceram os mesmos, a aparente diminuição do badejo necessita ser investigada mais detalhadamente. Os resultados desse estudo fornecem informações sobre a reprodução do badejo, com maior época de desova na primavera (setembro-dezembro) e desova adicional durante o mês de abril, no sudeste do Brasil. Análises genéticas sobre amostras de 96 badejos obtidos ao longo da costa do Brasil foram conduzidas. A informação genética obtida para as espécies permitiu-nos determinar a proximidade genética relativa de $M$. acutirostris e Mycteroperca bonaci e obter informações úteis para a aquicultura e conservação. Os objetivos deste estudo são: a) obter dados sobre a atividade pesqueira (desembarque de capturas) de badejo (Comb grouper, Mycteroperca acutirostris) em Copacabana, Posto 6; b) verificar o período reprodutivo dos badejos capturados nas pescarias, ao longo do ano; c) desenvolver um grande número de marcadores SNPs, que podem ser úteis para estudos de populações de garoupa (Mycteroperca e Epinephelus); d) obter dados sobre o preço do badejo. Existem muitas lacunas no conhecimento sobre M. acutirostris; este estudo pretende adicionar dados sobre biologia e ecologia do badejo e ajudar a subsidiar objetivos de conservação.

Palavras-chave: badejo, comunidades pesqueiras, genética, Mycteroperca.

\section{INTRODUCTION}

Small-scale fisheries (SSFs) are ubiquitous along maritime coasts. Despite a significant lack of systematic data, such fisheries are a valuable food source for local populations and are 
an important source of income (Begossi et al., 2017; Béné, 2006). Small-scale fisheries account for approximately $50 \%$ of all fish captured for consumption worldwide; however, the lack of long-term monitoring in data-poor countries contributes to failures in fishery management (Kalidin et al., 2020).

Estimation of grouper populations and their distributions in coastal aquatic ecosystems is complex, as exemplified in a study on Dusky grouper (Lopes et al., 2019). Of course, even small-scale fisheries can impact aquatic fauna when considering late-maturing species and the reality that environmental problems are often not considered to be of primary importance by local authorities, as is the case in Brazil (Fearnside, 2019). On the other hand, it is known that SSFs can generally be sustainable even in developing countries (see examples of Caribbean and Latin American SSFs, such as those given by Salas et al. (2018)).

In this group are the "badejo", as they are called in Brazil. Their dorsal fins have 11 spines and 15-18 rays. They are coastal fish with high commercial value, and are considered to be "noble fish". Grouper are part of the Epinephelinae subfamily. Nevertheless, there is debate based on genetic data regarding whether the subfamily Epinephelinae should be treated as a family (Epinephelidae) rather than as a subfamily (Craig et al., 2011).

Mycteroperca acutirostris has a dark brown color and a head with long striations, and it is characterized by 11 dorsal spines and 15-17 rays and 50-56 rakers in the first branchial arch, along with a rounded caudal fin. It is associated with rocky bottoms (adults), and juveniles are found in shallow waters and mangrove areas; its major threat is fishing pressure (Craig et al., 2011; Figueiredo and Menezes, 1980). Our studies have shown that this species spawns in the spring in Brazil (Andreoli et al., 2016; Silvano et al., 2006).

Other species are addressed here, specifically in the genetic study, including Mycteroperca bonaci, called the Black grouper, which has a dark brown color and regular, hexagonal spots; it has, among other traits, truncated caudal fins and 11-16 gill rakers in the first branchial arch. It is a reef species, but juveniles can be found in estuarine environments (Craig et al., 2011; Figueiredo and Menezes, 1980). Another species included in the genetic study is Mycteroperca interstitialis, called the Yellowmouth grouper, which has small brown spots, 11 dorsal fins, 1618 rays, a first branchial arch with 15-19 gill rakers, and an emarginate caudal fin. It is also a reef species. We considered other species for the genetic study, especially because they are found in the coast of Brazil: M. acutirostris is common in the SE, whereas $M$. bonaci is common in NE Brazil. $M$. interstitialis is found in both regions, among others.

These species are monandric hermaphrodites, and $M$. bonaci forms spawning aggregations. Fishing pressure is one of the main threats to these species; adults occupy reef habitats, and juveniles are found in estuarine and mangrove environments. Adults feed on fish (Craig et al., 2011).

When searching in FishBase (Froese and Pauly, 2020) and the IUCN Red List (data from 2016 for these fish) for Mycteroperca acutirostris (Comb grouper), we found that the knowledge about this species had several gaps. There are gaps for $M$. acutirostris, which include important information, such as diet and reproduction. The available information is general (and is based on few studies) such as the following: It has high vulnerability and is expensive; there is no information regarding eggs, spawning processes, or periods; and food items are mentioned as "unidentified invertebrates" (Froese and Pauly, 2020). Nevertheless, it is considered to be a species of LC (least concern), and its population is estimated as stable (IUCN, 2020b). For Mycteroperca bonaci, for example, we found slightly more biological information (Froese and Pauly, 2020): spawning in Brazil (one study including other fish species) in the period of June-December occurs for M. bonaci (Trindade-Santos and de Meirelles Felizola, 2015), and its diet was unidentified. $M$. bonaci is considered to be NT (near threatened, population decreasing) (IUCN, 2020a). For Mycteroperca interstitialis (Yellowmouth grouper), we found some information regarding reproduction (a study in the United States) showing that its reproduction occurs in all months of the year and its diet consists of "nekton" (a study in Puerto Rico) (Froese 
and Pauly, 2020). It is considered to be VU (vulnerable), and its population is decreasing (IUCN, 2020a). For Mycteroperca interstitialis (Yellowmouth grouper), we found some information regarding reproduction (a study in the United States) showing that its reproduction occurs in all months of the year and its diet consists of "nekton" (a study in Puerto Rico) (Froese and Pauly, 2020). It is considered to be VU (vulnerable), and its population is decreasing (IUCN, 2020a).

Epinephelus marginatus is found in the Atlantic and in the western Indian Ocean. It has a decreasing population trend and is considered by the IUCN to be "EN" (endangered); Mycteroperca acutirostris is found in the western Atlantic and is considered to be heavily fished, but it is viewed by the IUCN to be of "LC" (least concern) (Craig et al., 2011; Froese and Pauly, 2020).

Given the lack of data on Comb grouper (M. acutirostris), our objectives in this study were: a) to obtain data about the fishing activity of the Comb Grouper (M. acutirostris)(spots used, landings); b) to obtain data on its reproductive period (s) throughout the year; c) to develop a large numbers of SNPs markers, which can be useful to studies of grouper populations (Mycteroperca and Epinephelus); and, d) to obtain data on the price of the Comb grouper (price fluctuation can probably be used indirectly evaluate resource availability). It is important to mention here that even though we included some genetic data for other species of Mycteroperca in this study, which allows us to make comparisons, our main focus is the study of $M$. acutirostris in the Copacabana fishery of Posto 6, since we have been following its catches for two periods since 2013.

For the genetic study, our objective was to use genotyping by sequencing to rapidly develop a large number of SNPs markers. These markers can be useful in future studies to improve genetic inferences within each species of Mycteroperca and Epinephelus here related to (among others) migration and population structure in a cost-effective manner (Bernos et al. 2020). We also examine whether divergence among these grouper genera and species are consistent with the early division proposed by Ma and Craig (2018).

\section{MATERIAL AND METHODS}

\subsection{The fishery at Posto 6, Copacabana}

The main fishing locations of the studied individuals of Dusky grouper and Comb grouper caught in 2013-2014 and 2018-2020 were the area in 2-7 km south from Copacabana Beach, where a lot of archipelagos and islands are located: Cagarras Islands, Tijucas Islands, Redonda Islands, Rasa Island and others (Figure 1).

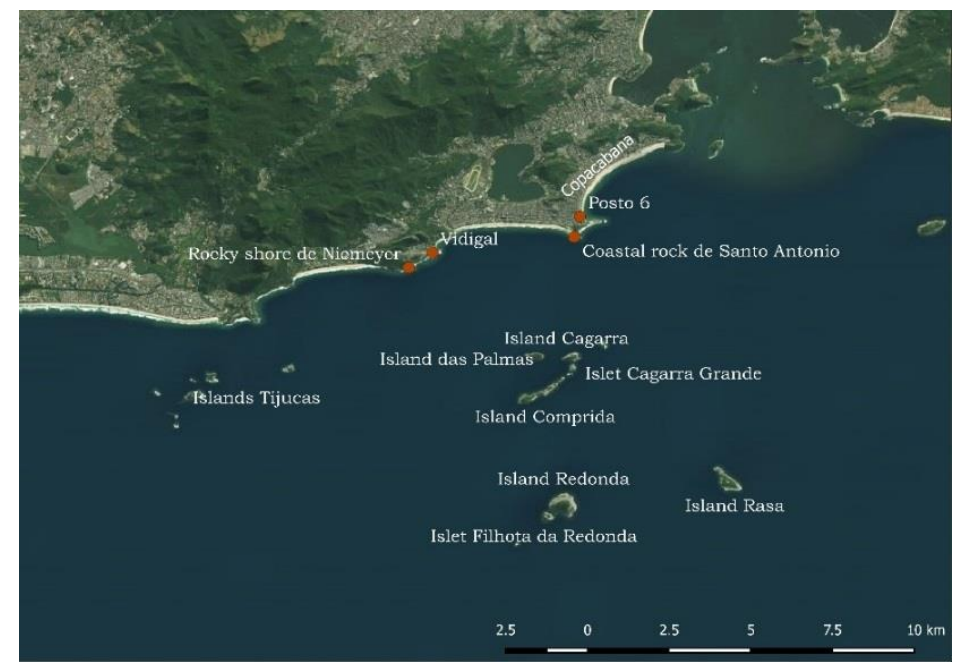

Figure 1. Fishing Locations Used for Dusky grouper and Comb grouper (2013-2018). 
The "Colônia de Pescadores do Posto 6" includes a small-scale fishing community on Copacabana Beach that was established in 1923. Fishing is conducted from small motorboats by using set gillnets, hooks and lines and by spearfishing (Begossi et al., 2013; 2019). Recently, spearfishing by diving has become important, especially among young fishers. Fishing effort has been similar over the last 11 years: there are approximately 20-25 active fishers, including approximately 10 divers who spearfish close to islands.

Fieldwork at Copacabana was undertaken from September 2013 to February 2020 at the landing point or fish market of Posto 6, Copacabana. One of the authors (AB) visited approximately 5 days/month and compiled information on weight, price, and location, among other data. Two fishers were trained to follow a protocol that is explained in detail in Begossi (2008) and was used in Begossi et al. (2012; 2016; 2019). These methods included local knowledge, tracking fishery landings (systematic visits 3-5 days/month), including fishing locations, weight and length measurements (TL), and reproduction (gonad macroscopic analysis), which were the same as in the earlier studies [detailed in (Begossi and Silvano, 2008; Begossi et al., 2019)]. Macroscopic gonad analysis included the observation (naked eye) of the presence or absence of mature gonads. Garoupa, or Dusky grouper (E. marginatus), was observed in 2013-2018, and Comb grouper (M. acutirostris) was observed in two periods, namely, 2013-2014 and 2018-2020.

This study follows a series of studies on small-scale fishing for grouper, especially Epinephelus marginatus (Dusky grouper) and Mycteroperca acutirostris (Comb grouper), that began in 2006 for both the Dusky grouper (Begossi and Silvano, 2008) and Comb grouper (Andreoli et al., 2016) at the Colônia de Pescadores do Posto 6 in Copacabana, Rio de Janeiro, Brazil.

Here, we chronologically describe the research results for garoupa, Dusky grouper. The most recent study (Begossi and Salivonchyk, 2019) showed relative catches and price stability. The studies that were begun by Begossi and Silvano (2008) included results about the local knowledge of fishers regarding diet and habitat, fishing locations, weight and length (TL), and stomach contents, among other features (sample of 40 individuals from 2006-2007). This study was followed by that of Begossi et al. (2016), which included fishing locations (Figure 1), weight and length (TL), macroscopic analysis of gonads by trained fishers (800 individuals from 2013 to 2015); Begossi et al. (2019): locations, weight and length (TL), macroscopic analysis of gonads by trained fishers (sample of 222 individuals, from 2016-2017), and prices from October, 2016 to November, 2017; and the study by Begossi and Salivonchyk (2019): 1,896 grouper observed from 2013-2018, showing catches and prices as relatively stable in Copacabana (the https://www.biorxiv.org/content/10.1101/759357v1). Genetic analyses were performed earlier for Dusky grouper (Priolli et al., 2014; 2016).

Given the substantial gaps in knowledge about an important food species and for the market, we believe that these original and previously unpublished data regarding M. acutirostris are important for conserving this species.

\subsection{Genetics of grouper}

\subsubsection{Sampling of fins for genetic analyses}

A total of 96 samples were obtained along the coast of Brazil (see details in (Begossi et al., 2019)) from specimens belonging to two genera (Epinephelus and Mycteroperca) and five grouper species: E. marginatus $(\mathrm{N}=28)$, E. morio $(\mathrm{N}=19)$, M. acutirostris $(\mathrm{N}=16)$, M. bonaci $(\mathrm{N}=27)$, and $M$. interstitialis $(\mathrm{N}=6)$. All individuals were caught by commercial fishers and identified based on their morphological characteristics as described in Begossi et al. (2019).

\subsubsection{Molecular techniques}

Total genomic DNA was extracted from approximately $20 \mathrm{mg}$ of tissue using a DNeasy 
Alpina Begossi et al.

Blood and Tissue Kit (Qiagen, Hilden, GE). DNA concentrations were estimated using a Qubit v4.0 fluorometer (Thermo Fisher Scientific, Waltham, USA). Thermo Fisher Scientific) and were normalized to $20 \mathrm{ng} / \mu \mathrm{L}$. Genomic libraries were constructed according to the Genotypeby-Sequencing double digestion protocol described by Poland et al. (2012), using the restriction enzymes $N$ siI (NEB, Ipswich, USA) and MseI (NEB). The resulting libraries were pooled at 96-plex and sequenced on the Illumina NextSeq 500 platform (Illumina, Inc, USA) at the Hemocentro of Ribeirão Preto facilities (Brazil), in mid-output mode and set to produce $150 \mathrm{bp}$ single-end reads. The quality of the obtained raw reads was assessed using FastQC software (http://www.bioinformatics.babraham.ac.uk/projects/fastqc/) at the Hemocentro of Ribeirão Preto facilities (Brazil).

For each genus, samples were demultiplexed, and the raw read sequences were filtered with the module "process_radtags" in the Stacks program (Version 1.42) (Catchen et al., 2013). SNP calling retained only SNP per sequenced tag, with a minimum sequencing depth of $5 \mathrm{X}$, minor allele frequency $\geq 0.05$ and occurring in at least $90 \%$ of individuals within each species. The SNP identification was performed considering each genus separately, and also for the five species simultaneously. Population genomic analyses were performed by applying additional filtering parameters to obtain the maximum-quality SNPs: 1) individual samples with $>55 \%$ missing data were excluded, and 2) SNPs with missing data in $25 \%$ of the samples or a minor allele frequency (MAF) $<0.05$ were removed.

\subsubsection{Genetic analyses}

The filtered data were imported as a genind object into $\mathrm{R}$ and were analyzed mainly by using several packages for population genetics. An outlier locus approach was taken using the R packages PCAdapt Version 3.0.4 (Luu et al., 2017) and fsthet (Flanagan and Jones, 2017) and the software package SelEstim (Vitalis et al., 2014), and only the loci that were identified as outliers by at least two of the three methods were considered as candidates for selection. The number of groups considered in fsthet and SelEstim analyses were three for Mycteroperca two for Epinephelus (corresponding to the number of species within each genus). The outputs from these analyses were used to create a neutral loci dataset and an adaptive loci dataset for further analysis. Neighbor-joining trees were generated for both the neutral and outlier datasets using Nei's genetic distance method. Analyses of population structure were performed using discriminant analysis of principal components (DAPC) with the 'Adegenet' package (Jombart, 2008).

\section{RESULTS AND DISCUSSION}

We observed a total of 490 individuals, among which weights were obtained for 466 individuals and showed a total catch of $630.39 \mathrm{~kg}$. The average catch was $1.36 \mathrm{~kg}$. While 410,55 $\mathrm{kg}$ was obtained in 2014, we observed a relative decrease in Comb grouper catches, with 2019 being the year in which the species became rare in Copacabana fishing catches, and this trend continued in 2020. The number of individuals and the weights of Comb grouper found and studied at the landing point and fish market at Posto 6, Copacabana significantly varied by year and month (Tables 1 and 2).

Mature gonads for Comb grouper were observed in April, September and October: these spring months coincide with mature gonads being observed in Dusky grouper (Begossi and Lopes, 2020; Begossi and Salivonchyk, 2019; Begossi et al., 2019) (Figure 2). The months mentioned by fishers from Copacabana (13 fishers) as the months in which Comb grouper was "ovado" (with mature gonads) were September ( 5 fishers) and November-December ( 8 fishers).

Rev. Ambient. Água vol. 17 n. 1, e2774 - Taubaté 2022 
Table 1. Comb grouper (badejo) observed at Copacabana fishery from 2013 to 2021. The data in parentheses indicate the number of individuals for which the weight was determined, when it was not possible to weigh the fish caught. Total number of individuals is 490 and weight $(\mathrm{kg})$ was obtained for 464 individuals (*COVID period) (Table 2 ). In the COVID period of the study (May, 2020 to March 2021), occasional visits were made, and two trained fishers contributed through whatsapp, when possible. In this period of 27 days of observations (19 visits and 8 whatsapps), 19 M. acutirostris were observed.

\begin{tabular}{cccccc}
\hline Month & 2013 & 2014 & 2018 & 2019 & 2020 \\
\hline Jan & & 14 & & & $23(3)$ \\
Feb & & 32 & 1 & & $10(5)$ \\
Mar & & 12 & & & 2 \\
Apr & & 26 & $3(2)$ & & $*$ \\
May & & 116 & & & $*$ \\
Jun & & 28 & & & $*$ \\
Jul & & 46 & 13 & & $*$ \\
Aug & & 20 & 29 & & $*$ \\
Sep & 6 & & 17 & & $*$ \\
Oct & 34 & & 21 & & $*$ \\
Nov & 18 & & & 2 & $*$ \\
Dec & 3 & 1 & & 17 & $*$ \\
\hline Total & 61 & 291 & $84(83)$ & 19 & $35(10)$ \\
\hline
\end{tabular}

Table 2. Weight (kg) of the badejo (Comb grouper) caught at Copacabana fishery (2013-2020). Total weight is 630.39 $(\mathrm{n}=464$ individuals) and average catch is $1.36 \mathrm{~kg}$. For the COVID period (March 2020-March 2021), 27 days, the weight amounted to $42.4 \mathrm{~kg}(\mathrm{n}=19)$, average $2.23 \mathrm{~kg}$ per individual.

\begin{tabular}{ccccccc}
\hline Mon & 2013 & 2014 & 2017 & 2018 & 2019 & 2020 \\
\hline Jan & & 13.01 & & & & 6.90 \\
Feb & & 58.75 & 8.78 & 1.30 & & 4.20 \\
Mar & & 10.51 & & & & 2.50 \\
Apr & & 40.25 & & 1,05 & & \\
May & & 178.05 & & & & \\
Jun & & 23.16 & & & & \\
Jul & & 67.60 & & 24.77 & & \\
Aug & & 17.20 & & 55.89 & & \\
Sep & 5.17 & & & 34.70 & & \\
Oct & 35.98 & & & 22.68 & & \\
Nov & 13.39 & & & & 3 & \\
Dec & 11.30 & 2.00 & & & 33.41 & \\
\hline Total & 65.84 & 410.55 & 8.78 & 140.40 & 36.41 & 13.60 \\
\hline
\end{tabular}




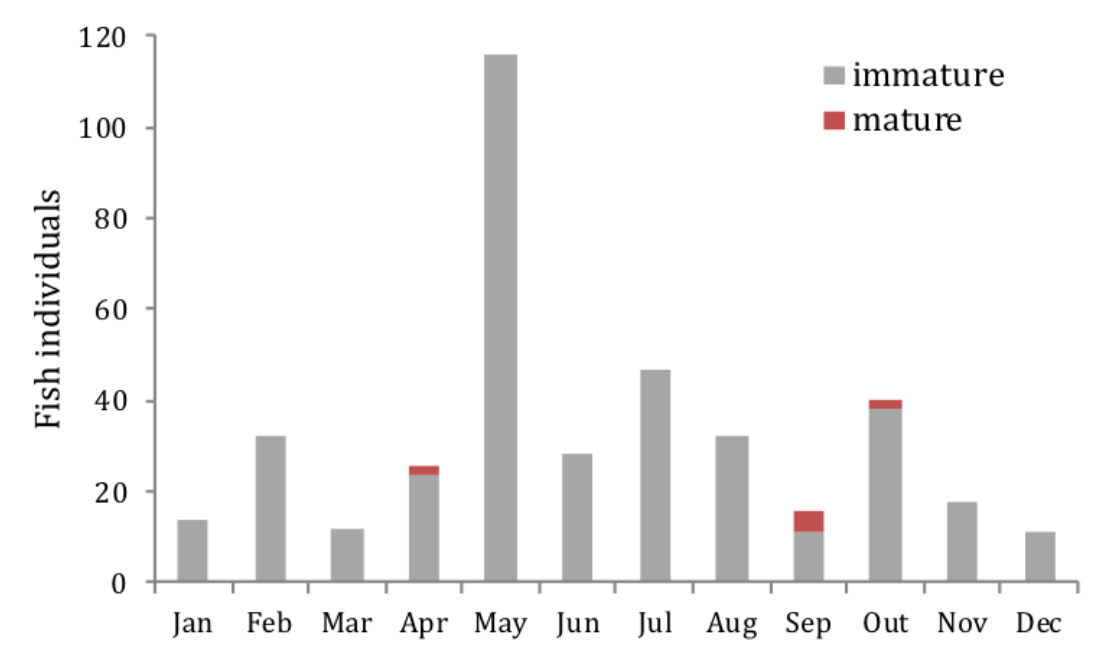

Figure 2. For the period 2013-2020, 392 individual Comb grouper were examined for gonads.

Mature gonads were observed in only 9 cases: 5 in September and 2 in April and October.

Prices were examined for April and July October of 2018. The average price of Comb grouper was 40.8 Reais $/ \mathrm{kg}$. The prices ranged from $26.5(26 / 07 / 2018)$ to 55.5 Reais $/ \mathrm{kg}$ (10/10/2018). The average daily prices varied from $36(11 / 04 / 2018)$ to 45.4 Reais/kg (10/10/2018) (the exchange rate on July 6, 2018, was 3.93 Reais; Figure 2). The average monthly prices were slightly higher in July and August than in other months. They fluctuated most strongly in July and October (Figure $3 a$ and $b$ ). The average exchange rate for 2018 was US $\$ 1.00=\mathrm{R} \$ 3.65$ )(https://www.exchangerates.org.uk/USD-BRL-spot-exchange-rates-history2018.html). Even though prices can be an indirect way to evaluate resource availability, in the observed months of 2018 we did not observe significant fluctuations that showed differences in the availability of the resource. Fish prices reflect fish unpredictability and its supply tends to be inelastic (Sathiadhas and Kumar, 1994). Actually, in 5 months of 2018, prices did have apparent fluctuations, but a long time series is needed to better evaluate the relationship between prices and supply of the Comb grouper in Copacabana, Rio. Price fluctuations were not noticed for Dusky grouper, in the same fishery (Begossi and Salivonchyk, 2019).

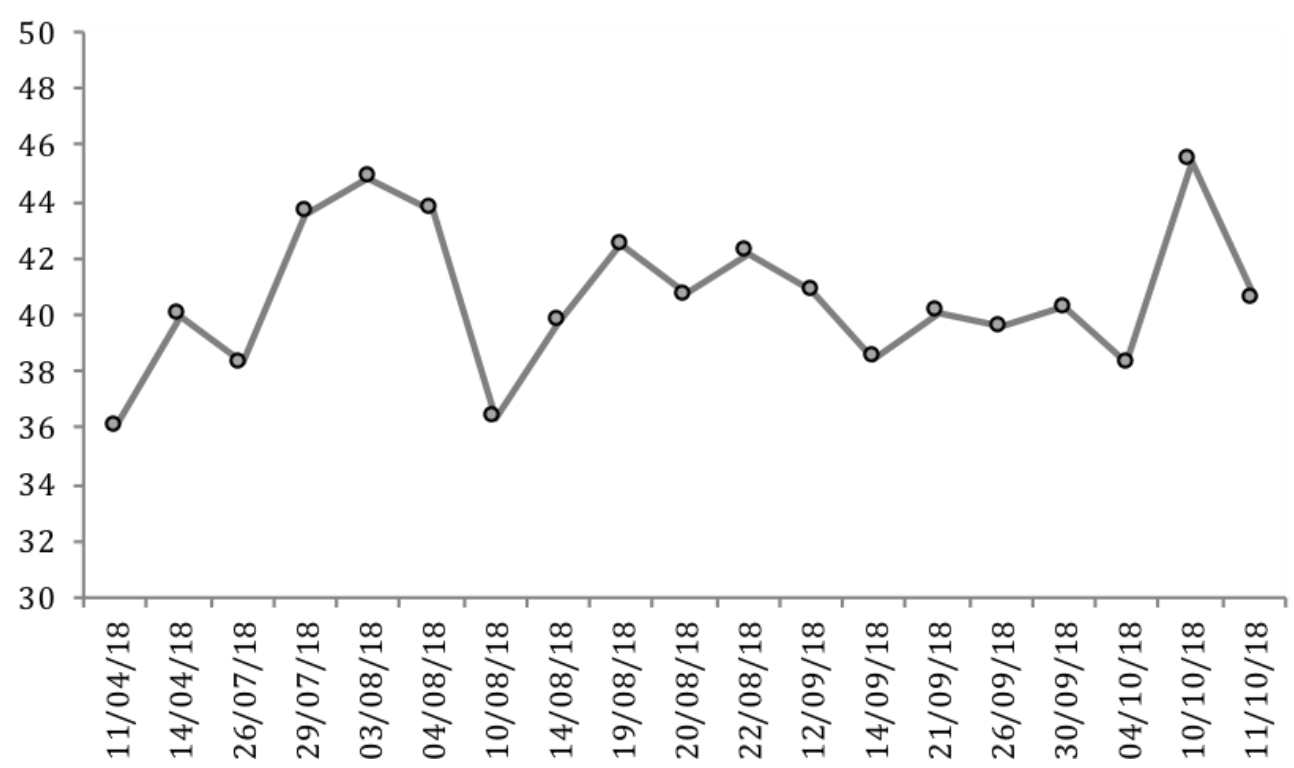

Figure 3a. Daily Average Price (in Brazilian Reais) per $1 \mathrm{~kg}$ of Comb Grouper in Copacabana (2018, US\$1.00=R \$3.65). 


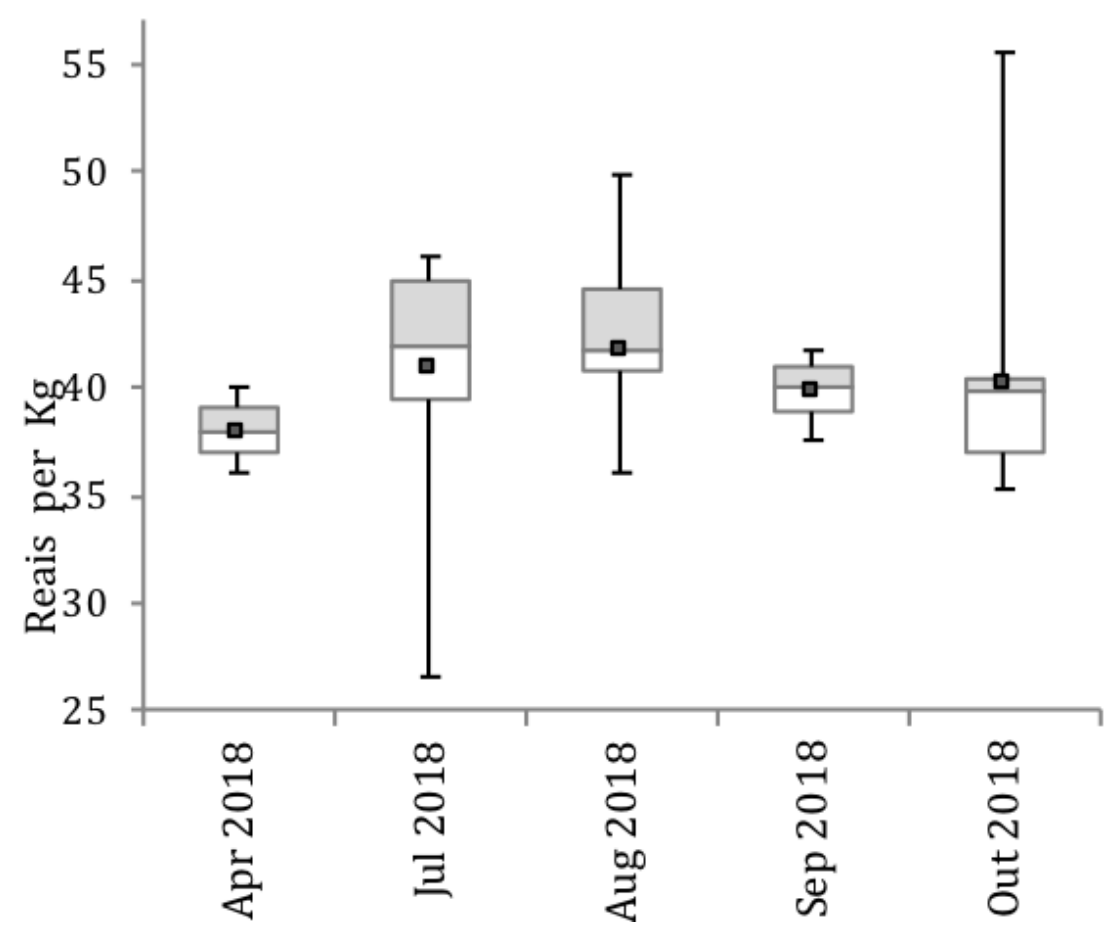

Figure 3b. Monthly Average Prices (in Brazilian Reais) per $1 \mathrm{~kg}$ of Comb grouper, in Copacabana (2018, US $\$ 1.00=\mathrm{R} \$ 3.65)$.

When comparing the yield (weight) of both species over the years, we observed higher catches for Dusky grouper, compared to Comb grouper, along with a decrease in Comb grouper in 2018 and 2019 (Figure 4).

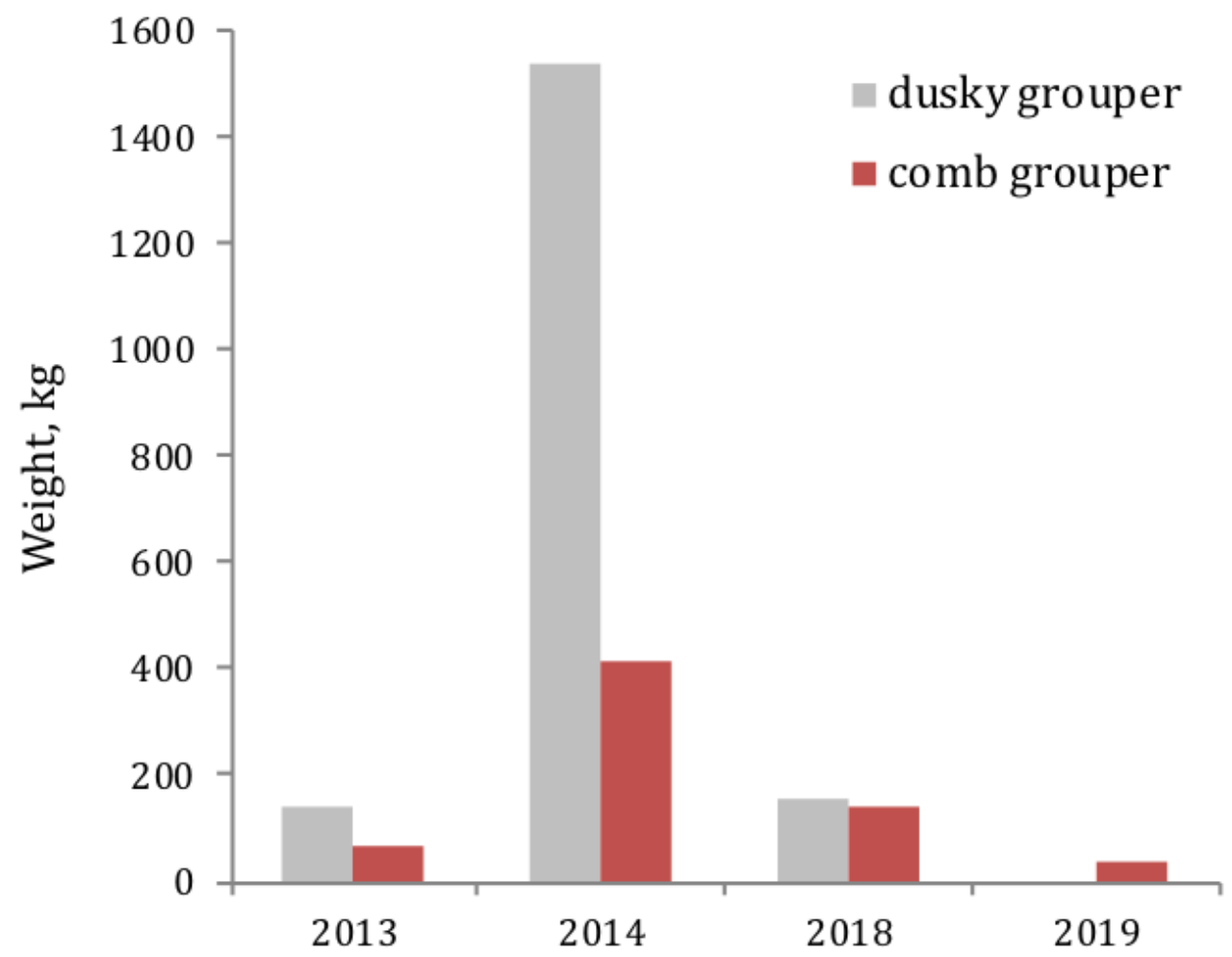

Figure 4. Annual Catches by Weight of Dusky grouper (A) and Comb grouper (B). The results from samples taken from September 2013 to February 2018 for and from September 2013-December 2014 and January 2018- December 2019 for Comb grouper at the Copacabana fishing post. 


\subsection{Genetic identification of groupers in the coast of Brazil}

Sequencing of GBS libraries produced 150,458,819 raw reads for the 96 grouper, and $139,429,799$ reads were retained following "process_radtags" filtering. After applying the Stacks pipeline to each genus and additional filtering, 1,313 SNP loci were identified in 43 individuals of Mycteroperca (M. acutirostris $=16, M$. bonaci $=23$ and $M$. interstitialis $=4)$. For Epinephelus, 3,528 SNP loci were identified in 45 individuals (E. marginatus $=27$ and E. morio =18) (Figures A1 and A2, Appendix).

Outlier analyses identified 38 total consensus outlier loci in the three Mycteroperca species. Population structure analyses were conducted using the remaining 1,275 SNPs that were deemed to be neutrally evolving after outlier analyses. Overall, FST was 0.95 and highly significant $(\mathrm{p}<.001)$, while the species pairwise values varied from 0.935 to 0.967 .

The high genetic divergence suggested by the pairwise F $_{\text {ST }}$ estimates was also observed in the DAPCs. For Mycteroperca, the analysis based on SNPs with neutral behavior retained two principal components, which explained almost $92 \%$ of the total variation and clearly showed that samples of M.acutirostris, M. bonaci and M. interstitialis were highly distinct from each other (Figure 5a). For Epinephelus, the analyses based on SNPs with neutral behaviour retained one principal component, which explained more than $89 \%$ of the total variation and showed that samples of E. marginatus and E. morio were highly distinct (Figure 5b).

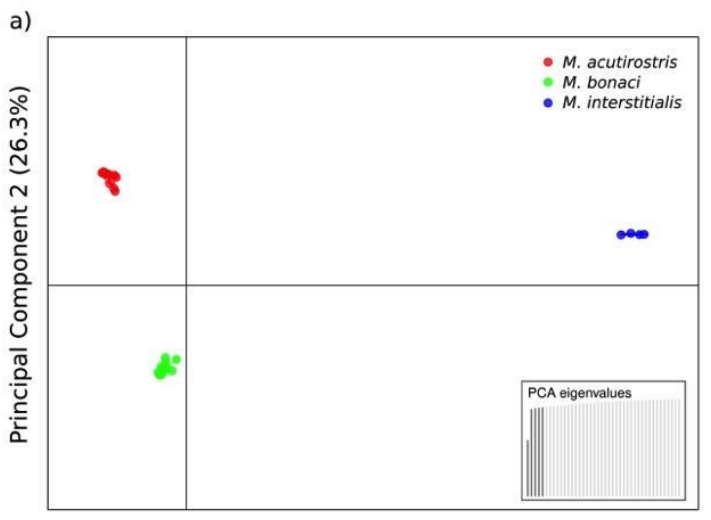

Principal Component 1 (65.3\%)

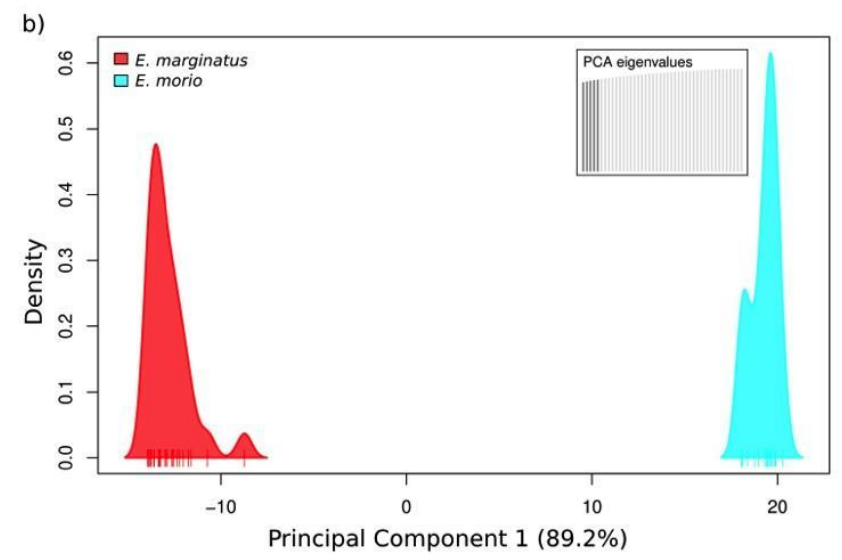

Figure 5. DAPC results for the genus Mycteroperca and Epinephelus. In a), samples of M. acutirostris, $M$. bonaci, and $M$. interstitialis are represented by colored dots, and their dispersal along the first two components is shown. In b), samples of E. marginatus and E. morio are represented by colored horizontal ticks along the first principal component and their density is represented in the vertical axis.

The same clustering patterns were observed for the neighbor-joining trees using both the neutral (A) and outlier (B) datasets for Mycteroperca (Figure A1) and Epinephelus (Figure A2). Outliers loci showed the species more divergent than neutral loci in both trees confirming the power of these for assigning individuals.

The genetic distances between the five grouper species (Figure 6) were determined from a set of neutral SNP loci and revealed that $M$. acutirostris is more closely related to $M$. interstitialis (0.343) than to M. bonaci (0.48). Epinephelus morio was the species that was most distant from the others, even for the species from the same genus, E. marginatus (0.73). Mitochondrial molecular markers and ribosomal genes showed E. morio in a branch different from $M$. acutirostris, $M$. bonaci and $M$. interstitialis; while E. marginatus was reclassified by the authors as Mycteroperca marginatus because was in the same monophyletic branch (Ma and Craig, 2018). In Figure 6, neighbor-joining tree based on Nei's genetic distances was produced using the set of 817 SNP loci identified with Stacks pipeline considering all the five grouper species simultaneously. 


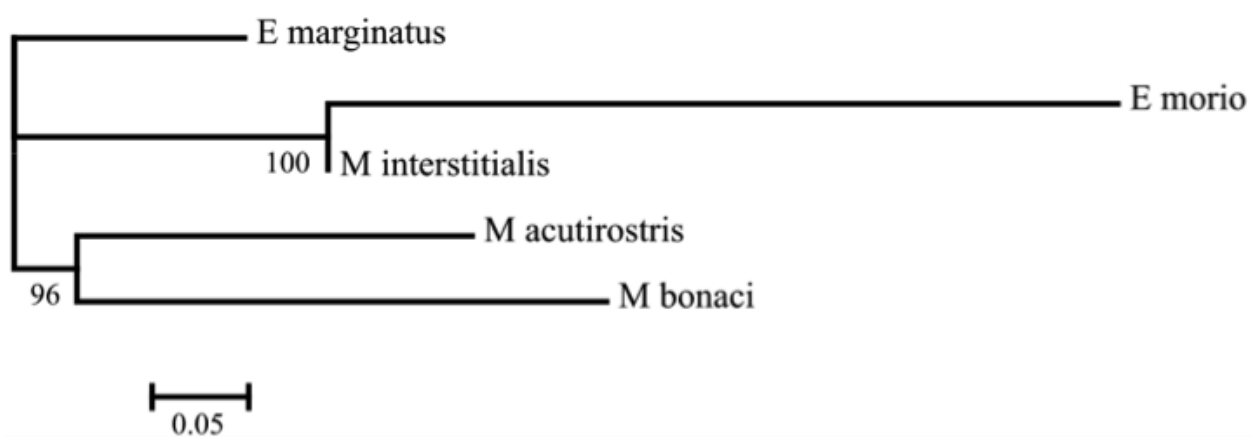

Figure 6. Neighbor-joining trees based on Nei's genetic distances. Branch nodes are denoted as the percentage of bootstrap support that was generated with 1,000 replicates.

\section{CONCLUDING REMARKS}

Exploratory research is very important for species that require management, especially species that are important for human consumption and for the livelihoods of poor communities that depend on small-scale fisheries for consumption and cash. This study provides important information for the conservation of this species and provides information on the reproduction period and on genetics that may be useful for managing this species. In addition, it provides alerts for a species that is becoming scarce and for a species with poor data and that is still considered of LC (least concern).

In this study, we found different catch patterns for each of the grouper species, namely, stability of catches and prices for Dusky grouper, but a decreasing pattern in the catches of Comb grouper, for the Copacabana small-scale fishery. We added genetics to better understand the species and to gain insights into their conservation and biology. With this study, we hope to fill some knowledge gaps in Brazil and contribute to management efforts.

By comparing catches of Dusky grouper and Comb grouper, contrasting patterns are found in the catches of the studied groupers: while we found relative stability for the catches of Dusky grouper, we found very irregular and decreasing catches in terms of number and weight for Comb groupers. Even considering that Comb grouper is of LC (least concern, IUCN Red List), there is an information gap concerning its diet and reproduction (Froese and Pauly, 2020). Thus, an optimistic prognosis is offered from the studies of Dusky grouper and Copacabana (Begossi and Salivonchyk, 2019), but there is a pessimistic prognosis for Comb grouper due to its decreasing catches when the fishing effort is maintained at a constant level, as was observed for the Copacabana fishery. Even though prices can help reveal the decrease or increase in the abundance of noble fish species for the market, such as $M$. acutirostris, the results did not add much for that objective. Lon- term analysis of price fluctuation could add to this kind of estimation. Therefore, the results obtained from the landing points of Copacabana show decreases in catches: fishers report the fish must be obtained farther, at more distant areas and that it has been scarcer in the catches.

The results about the genetic diversity of the five species of grouper showed that E. morio is more distant than the other four species and that neutral and outlier SNPs are powerful to identify and to assign individuals.

How could these data aid in the conservation of species? Such information can help directly and indirectly.

Directly, information regarding the reproduction period is helpful for managing fish resources, as fishing closures for Comb grouper in the spring could help maintain stocks. Information on diet, in addition to its importance in maintaining available prey, could provide insights for possible aquaculture, which exists in SE Brazil for Dusky grouper (Glamuzina, 
2020; Kerber, 2020).

Indirectly, grouper genetics data can provide basic information for aquaculture; it engenders information that could aid in conservation for assigning individuals in future studies. Here, genetic information could also be helpful for taxonomic analysis of the subfamily Epinephelus. Grouper systematics has been reevaluated, restricting the genus Epinephelus and expanding Mycteroperca when several species of Epinephelus were included in Mycteroperca, including E. marginatus (Craig et al., 2011; Ma and Craig, 2018).

Summing up, the fishing locations found for the catch of Comb groupers by fishers of Posto 6 are relatively close to the coast of Copacabana, including rocky shores, such as islands of Cagarras, Redonda, among others (Figure 1). Average catch was 1.36 ( $\mathrm{n}=446$ individual). Mature gonads were found especially in the spring (September, October), but also in April (Autumn). Prices did not show conspicuous fluctuations in the observed months of 2018, indicating minor fluctuations in a resource that was already scarce in 2018 (the year in which prices were collected). GBS libraries revealed 1,313 SNP loci to Mycteroperca and 3,528 SNP loci to Epinephelus which can be useful in future studies to improve genetic inferences in each species.

\section{ACKNOWLEDGEMENTS}

We are grateful to the fishers Antonio, Elenilson ("Jaguriçá") and Raul; Ana helped with data from the Marimbás Club, Copacabana. AA-P thanks FAPESP (\# 2018/00036-9) for a postdoctoral scholarship. AB is grateful to the productivity scholarship from CNPq (\# 301592/20179), for the grant FAPESP \# 14/16939-7, and for IDRC/UNICAMP grant (2019-2014). AA-P thanks FAPESP (\# 2018/00036-9) for a post-doctoral scholarship. We are very grateful to Alline A. L. Tribst for the support in the laboratory, in the material extraction of the fish, at NEPA/UNICAMP, Campinas, Brazil.

\section{COMPLIANCE WITH ETHICAL STANDARDS}

This research was approved and signed by B. R. Martins dos Santos, Comitê de Ética, Universidade Santa Cecília, number 1.747.889 on September 27, 2016 (Plataforma Brasil). It is approved under number 53824 at the SISBIO and is registered under number AB53669 at the SISGEN, MMA (Ministério do Meio Ambiente, Brasil). No animal ethics committee was relevant for this study, since all specimens were collected dead from fishery markets, and specimens were caught by small-scale fishers through artisanal methods. Anesthesia, euthanasia or animal sacrifices are not part of the methods used in this study.

\section{REFERENCES}

ANDREOLI, T. B.; RAMIRES, M.; CLAUZET, M.; BEGOSSI, A. Comb grouper (Mycteroperca acutirostris): information from catches at Copacabana, Rio de Janeiro, Brazil. Journal of Marine Science: Research and Development, v. 6, n. 200, p. 2, 2016. http://dx.doi.org/10.4172/2155-9910.1000200

BEGOSSI, A. Local knowledge and training towards management. Environment, Development and Sustainability, v. 10, n. 5, p. 591-603, 2008. https://doi.org/10.1007/s10668-008-9150-7

BEGOSSI, A.; CAMARGO, E.; CARPI, S. Os mapas da pesca artesanal - pesqueiros e pescadores na costa do Brasil. Sao Carlos: RiMa, 2013. 
BEGOSSI, A.; LOPES, P. F. Garoupas e pescadores. São Carlos: RiMa, 2020.

BEGOSSI, A.; SALIVONCHYK, S.; HALLWASS, G.; HANAZAKI, N.; LOPES, P. F. M.; SILVANO, R. A. M. Threatened fish and fishers along the Brazilian Atlantic forest coast. Ambio, v. 46, n. 8, p. 907-914, 2017. https://doi.org/10.1007/s13280-017-0931-9

BEGOSSI, A.; SALIVONCHYK, S.; SILVANO, R. Collaborative research on Dusky grouper (Epinephelus marginatus): catches from the small-scale fishery of Copacabana Beach, Rio de Janeiro, Brazil. Journal of Coastal Zone Management, v. 19, n. 428, p. 21-23, 2016. http://dx.doi.org/10.4172/2473-3350.1000428

BEGOSSI, A.; SALIVONCHYK, S. V. Integrating science and citizen science: the Dusky grouper (Epinephelus marginatus) sustainable fishery of Copacabana, Rio de Janeiro, Brazil. p. bioRxiv, n. 759357, 2019. https://doi.org/10.1101/759357

BEGOSSI, A.; SALIVONCHYK, S. V.; BARRETO, T.; NORA, V.; SILVANO, R. A. M. Small-scale fisheries and conservation of Dusky grouper (garoupa), Epinephelus marginatus (Lowe, 1834) in the southeastern Brazilian coast. Science Journal of Agricultural Research and Management, v. 2012, p. 1-4, 2012.

BEGOSSI, A.; SALYVONCHYK, S.; GLAMUZINA, B.; DE SOUZA, S. P.; LOPES, P. F. M.; PRIOLLI, R. H. G. et al. Fishers and groupers (Epinephelus marginatus and E. morio) in the coast of Brazil: integrating information for conservation. Journal of Ethnobiology and Ethnomedicine, v. 15, n. 1, p. 1-26, 2019. https://doi.org/10.1186/s13002-019-03312

BEGOSSI, A.; SILVANO, R. A. M. Ecology and ethnoecology of Dusky grouper [garoupa, Epinephelus marginatus (Lowe, 1834)] along the coast of Brazil. Journal of Ethnobiology and Ethnomedicine, v. 4, n. 1, p. 1-14, 2008. https://doi.org/10.1186/1746-4269-4-20

BÉNÉ, C. Small-scale fisheries: assessing their contribution to rural livelihoods in developing countries. FAO Fisheries Circular, v. 1008, p. 46, 2006.

BERNOS, T. A.; JEFFRIES, K. M.; MANDRAK, N. E. Linking genomics and fish conservation decision making: a review. Reviews in Fish Biology and Fisheries, v. 30, p. 587-604, 2020. https://doi.org/10.1007/s11160-020-09618-8

CATCHEN, J.; HOHENLOHE, P. A.; BASSHAM, S.; AMORES, A.; CRESKO, W. A. Stacks: an analysis tool set for population genomics. Molecular Ecology, v. 22, n. 11, p. 31243140, 2013. https://doi.org/10.1111/mec.12354

CRAIG, T. M.; DE MITCHESON, Y. J. S.; HEEMSTRA, P. C. Groupers of the world: a field and market guide. Grahamstown: CRC Press, 2011.

FEARNSIDE, P. M. Hidrelétricas na Amazônia brasileira: questões ambientais e sociais. Hidrelétricas na Amazônia, v. 7, p. 37-82, 2019.

FIGUEIREDO, J. L.; MENEZES, N. A. Manual de peixes marinhos do sudeste do Brasil. São Paulo: Museu de Zoologia, Universidade de São Paulo, 1980.

FLANAGAN, S. P.; JONES, A. G. Constraints on the F $_{S T}$-heterozygosity outlier approach. $\begin{array}{llllllll}\text { Journal of Heredity, v. 108, n. 5, p. 561-573, } 2017 . & \end{array}$ https://doi.org/10.1093/jhered/esx048 
FROESE, R.; PAULY, D. FishBase World Wide Web electronic publication. 2020. Available in: www.fishbase.org, version. Access: December 2020.

GLAMUZINA, B. Groupers fishery and aquaculture in the Mediterranean. In: BEGOSSI, A.; LOPES, P. F. M. (eds.). Garoupas e pescadores (Groupers and fishers). São Carlos: RiMa, 2020. p. 98-103.

IUCN. Black grouper. 2020. Available in: https://www.iucnredlist.org/search?query=Mycteroperca\%20bonaci\&searchType=speci es. Access: February 2021.

IUCN. Comb grouper. 2020. Available in: https://www.iucnredlist.org/species/132830/46918685. Access: February 2021.

JOMBART, T. adegenet: a $\mathrm{R}$ package for the multivariate analysis of genetic markers. $\begin{array}{lllllll}\text { Bioinformatics, } & \text { v. } 24, \quad \text { n. } 11, \quad \text { p. } & 1403-1405,\end{array}$ https://doi.org/10.1093/bioinformatics/btn129

KALIDIN, B. K.; MATTONE, C.; SHEAVES, M. Barriers to effective monitoring and evaluation of small-scale fisheries in small island developing states: an example from $\begin{array}{llllll}\text { Mauritius. Marine Policy, v. } 2020 . & \end{array}$ https://doi.org/10.1016/j.marpol.2020.103845

KERBER, C. Avanços recentes de cultivo de garoupas no Brazil. In: BEGOSSI, A.; LOPES, P. F. M. (eds.). Garoupas e pescadores (Groupers and fishers). São Carlos: RiMa, 2020. p. 89-97.

LOPES, P. F. M.; VERBA, J. T.; BEGOSSI, A.; PENNINO, M. G. Predicting species distribution from fishers' local ecological knowledge: a new alternative for data-poor management. Canadian Journal of Fisheries and Aquatic Sciences, v. 76, n. 8, p. 1423 1431, 2019. https://doi.org/10.1139/cjfas-2018-0148

LUU, K.; BAZIN, E.; BLUM, M. G. B. pcadapt: an R package to perform genome scans for selection based on principal component analysis. Molecular Ecology Resources, v. 17, n. 1, p. 67-77, 2017. https://doi.org/10.1111/1755-0998.12592

MA, K. Y.; CRAIG, M. T. An inconvenient monophyly: an update on the taxonomy of the groupers (Epinephelidae). Copeia, v. 106, n. 3, p. 443-456, 2018. https://doi.org/10.1643/CI-18-055

POLAND, J. A.; BROWN, P. J.; SORRELLS, M. E.; JANNINK, J. L. Development of highdensity genetic maps for barley and wheat using a novel two-enzyme genotyping-bysequencing approach. PLoS One, v. 7, n. 2, p. e32253, 2012. https://doi.org/10.1371/journal.pone.0032253

PRIOLLI, R. H. G.; STABELLINI, N. S.; BAJAY, M. M. Diversidade genética de uma espécie em perigo de extinção: a garoupa Epinephelus marginatus. In: BEGOSSI, A.; LOPES, P. F. M. (eds.). Comunidades pesqueiras de Paraty - sugestões para manejo. São Carlos: RiMa, 2014. p. 27-40.

PRIOLLI, R. H. G.; BAJAY, M. M.; SILVANO, A. M.; BEGOSSI, A. Population genetic structure of an estuarine and a reef fish species exploited by Brazilian artisanal fishing. Scientia Marina, v. 80, n. 4, p.476-477, 2016. 
SALAS, S.; BARRAGÁN-PALADINES, M. J.; CHUENPAGDEE, R. Viability and sustainability of small-scale fisheries in Latin America and the Caribbean. Cham: Springer International Publishing, 2018.

SATHIADAS, P.; KUMAR, R. N. Price policy and fish marketing system in India. Journal of Biology Education, v. 11, n. 4, p. 225-241, 1994.

SILVANO, R. A. M.; MACCORD, P. F. L.; LIMA, R. V.; BEGOSSI, A. When does this fish spawn? Fishermen's local knowledge of migration and reproduction of Brazilian coastal fishes. Environmental Biology of Fishes, v. 76, n. 2, p. 371-386, 2006. https://doi.org/10.1007/s10641-006-9043-2

TRINDADE-SANTOS, I.; DE MEIRELLES FELIZOLA, F. K. Analysis of reproductive patterns of fishes from three large marine ecosystems. Frontiers in Marine Science, v. 2, p. 38, 2015. https://doi.org/10.3389/fmars.2015.00038

VITALIS, R.; GAUTIER, M.; DAWSON, K. J.; BEAUMONT, M. A. Detecting and measuring selection from gene frequency data. Genetics, v. 196, n. 3, p. 799-817, 2014. https://doi.org/10.1534/genetics.113.152991 


\section{Appendix:}

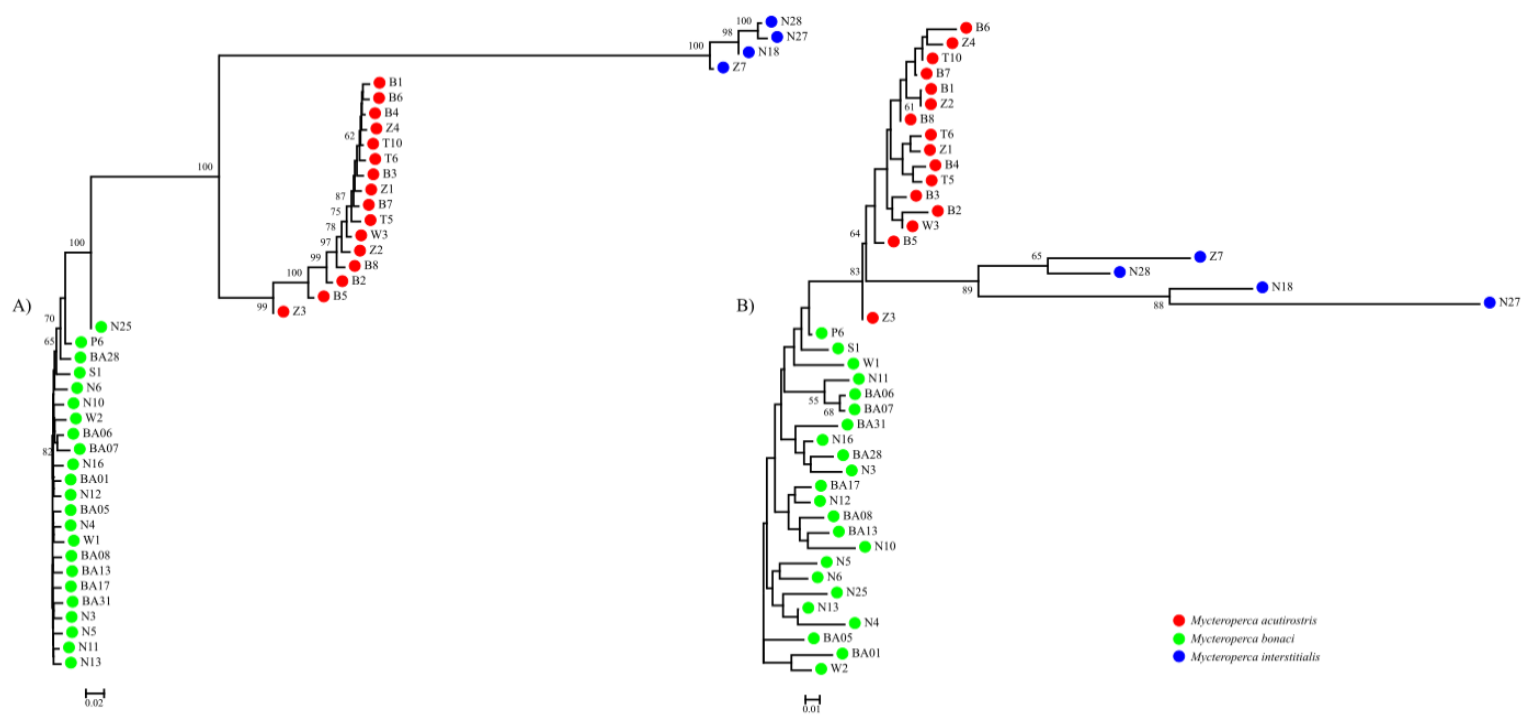

Figure A1. Neighbor-joining Trees Based on Nei's Genetic Distances using the Following Sets of Loci: (A) a panel of 1,275 putatively neutral SNPs and (B) a panel of 38 putatively adaptive SNPs. Branch nodes are denoted as the percentage of bootstrap support that was generated with 1,000 replicates. Collection codes correspond to M. acutirostis (red dots), M. bonaci (green) and M. interstitialis (blue).

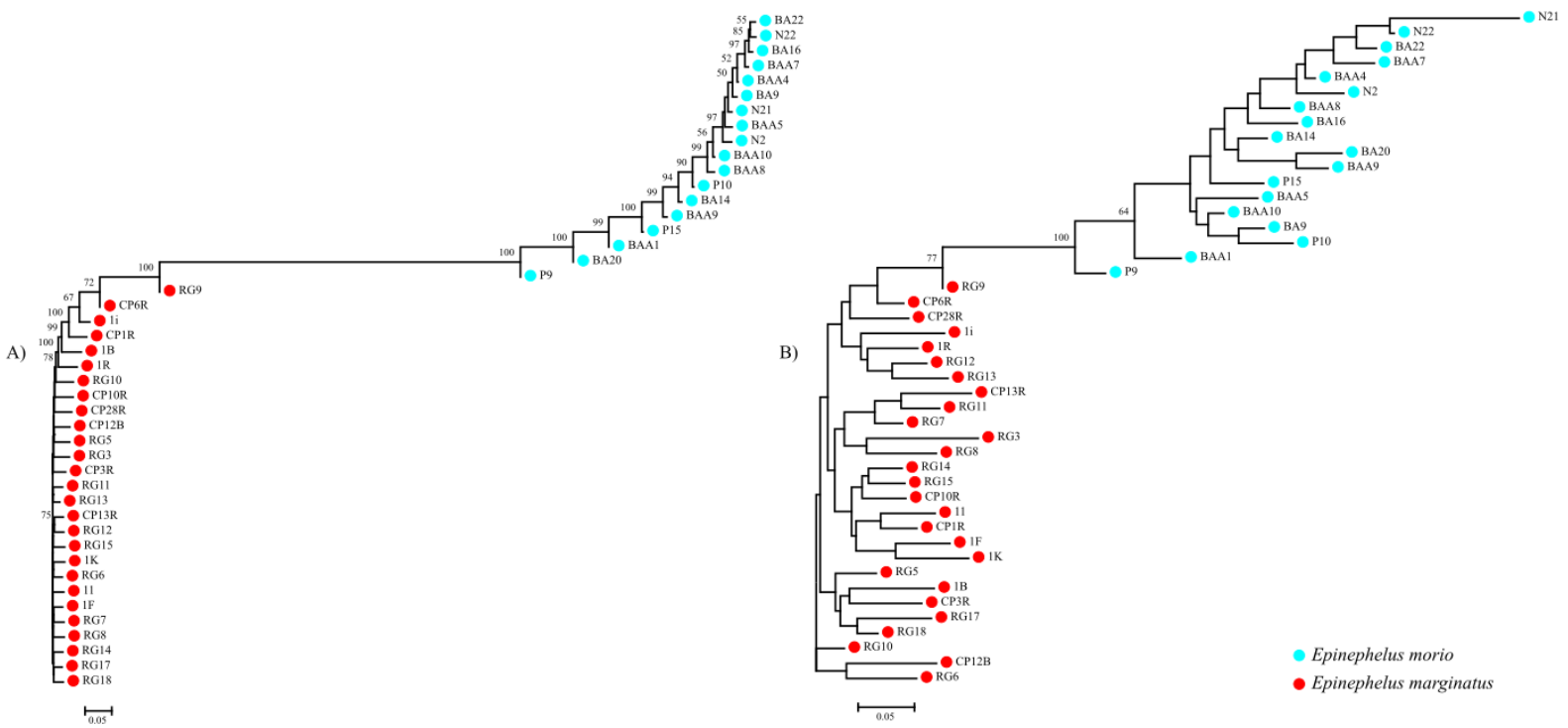

Figure A2. Neighbor-joining Trees Based on Nei's Genetic Distances Using the Following Sets of Loci: (A) a panel of 3,490 putatively neutral SNPs and (B) a panel of 38 putatively adaptive SNPs. Branch nodes are denoted as the percentage of bootstrap support that was generated with 1,000 replicates. Collection codes correspond to E. marginatus (red dots) and E. morio (blue). 